\title{
Enterobacterial Infections Diagnosed at the Clinic of Infectious Diseases of Fann Hospital (2013-2014) Dakar, Senegal
}

\author{
Khardiata Diallo Mbaye ${ }^{1 *}$, Ndèye Aissatou Lakhe ${ }^{1}$, Khadime Sylla ${ }^{2}$, Rahmatoulahi Ndiaye ${ }^{1}$, \\ Viviane Marie Pierre Cissé Diallo', Daye Ka ${ }^{1}$, Aminata Massaly ${ }^{1}$, Alassane Dièye1, \\ Louise Fortes Déguénonvo1, Cheikh Tacko Diop³ ${ }^{3}$ Cheikh Tidiane Ndour ${ }^{1}$, Masserigne Soumaré1, \\ Moussa Seydi ${ }^{1}$
}

\author{
${ }^{1}$ Clinic of Infectious Diseases, Fann National University Hospital, Dakar, Senegal \\ ${ }^{2}$ Laboratory of Parasitology-Mycology, Faculty of Medicine, Cheikh Anta Diop University, Dakar, Senegal \\ ${ }^{3}$ CommunityHealthDepartment, Health and SustainableDevelopment Training Unit and Research, Alioune Diop University, \\ Bambey, Senegal \\ Email: ^diallokhardiata@gmail.com, aissatoulakhe@gmail.com, khadimesylla@yahoo.fr, ndiayerahmatoulahi@yahoo.fr, \\ vivich6@gmail.com, dayeka10@gmail.com,massalyaminata@gmail.com,vieuxdieye87@yahoo.fr, \\ forteslouise@gmail.com, cheikhtackodiop@gmail.com, cheikh.t.ndour3@gmail.com, \\ soumarem@refer.sn, seydi.moussa@gmail.com
}

\begin{abstract}
How to cite this paper: Mbaye, K.D., Lakhe, N.A., Sylla, K., Ndiaye, R., Diallo, V.M.P.C., Ka, D., Massaly, A., Dièye, A., Déguénonvo, L.F., Diop, C.T., Ndour, C.T., Soumaré, M. and Seydi, M. (2018) Enterobacterial Infections Diagnosed at the Clinic of Infectious Diseases of Fann Hospital (2013-2014) Dakar, Senegal. Advances in Infectious Diseases, 8, 217-228. https://doi.org/10.4236/aid.2018.84018
\end{abstract}

Received: September 25, 2018

Accepted: November 13, 2018

Published: November 16, 2018

Copyright $\odot 2018$ by authors and Scientific Research Publishing Inc. This work is licensed under the Creative Commons Attribution International License (CC BY 4.0).

http://creativecommons.org/licenses/by/4.0/

(c) (i) Open Access

\begin{abstract}
Introduction: Entero bacteria are mainly found in the gut of man and animals. The frequent acquisition of antibiotic resistance mechanisms explains why they are the bacteria most often implicated in human infectious pathology. It is estimated to be involved in $50 \%$ of sepsis, $60 \%$ of enteritis, $70 \%$ of urinary tract infection case. Objective: To determine the prevalence of enterobacterial infections diagnosed at Fann Infectious Diseases Clinic, and describe their epidemiological, clinical, therapeutic and evolutionary aspects. Patients and Methods: This is a retrospective and descriptive study, on patients hospitalized from January 2013 to December 2014, at Fann Infectious Diseases Clinic, with bacteriological confirmation of an enterobacteria infection. Results: A total of 129 cases were collected during the study period. The average age was 41 years, and female were predominant (60\%) with a sex ratio of 0.67 . Comorbidity was found in $88.4 \%$ of the cases, most of which were HIV infection. The most common clinical signs were infectious syndrome (53.49\%) and general impairment (40.31\%). The main gateway was urinary (55.8\%). Samples were monomicrobial in $76.7 \%$ of cases. Klebsiella and Escherichia were the most common and $68.7 \%$ of the subjects had probabilistic treatment. Most enterobacterial strains were resistant to third generation cephalosporins (C3G), aminoglycosides to ciprofloxacin and cotrimoxazole.
\end{abstract}


Aside from $4 \%$ of them, all were sensitive to imipenem. Conclusion: The advent of antibiotics has brought hope in the treatment of enterobacterial infections. However, an increase in their resistance to the usual antibiotics has been noted in recent years. As a result, the fight against antibiotic resistance must be a priority.

\section{Keywords}

Dakar, Enterobacteria, Infections, Senegal

\section{Introduction}

Enterobacteria are the most common bacteria found in human pathology. There are optional Gram-negative bacilli (BGN) found in the soil, water, and especially in the gut of humans and animals. They are diverse and include a very large number of species. Their great number in the intestine, their mobility, their rapid multiplication and frequent acquisition of antibiotic resistance mechanisms explain why they are the bacteria mostly involved in human infectious pathology, especially in hospitals [1].

Enterobacterial infections are estimated to be involved in 50\% of sepsis cases, $60 \%$ of enteritis and $70 \%$ of urinary tract infection [2].

Today, hospital studies focus more and more on bacterial resistance, which is becoming very worrying at the global level [3]; this phenomenon is a real challenge when it comes to management of infections while limiting therapeutic options and generating high therapeutic costs.

In Senegal, a few studies have addressed enterobacteria cases, and more particularly at the Fann clinic of Infectious and Tropical Diseases (SMIT). Our study was carried out within this context and the main objectives were to assess enterobacterial infections diagnosed at SMIT. The specific objectives were to determine the prevalence, the epidemiological, clinical, therapeutic and evolutionary aspects.

\section{Patients and Methods}

This was a descriptive retrospective study based on the records of patient who have been hospitalized for infectious and tropical diseases collected over a 24-month period from January 1, 2013 to December 31, 2014. All the patients who were hospitalized at SMIT, bacteriologically confirmed with enterobacterial infection were included in this study during the study regardless of their status of HIV serology.

Epidemiological data (age, sex, geographical origin, occupation, marital status, status mainly HIV) and clinical data (reasons for hospitalization, associated diagnosis) were collected from patients' files.

From a paraclinical point of view, bacteriological data (isolated germs, antibi- 
ogram obtained (bacterial resistance), culture status (mono or polymicrobial) and biological (NFS, renal function, CRP, glycemia) were reported.

Therapeutic data (antibiotics used, duration of treatment, association or not), evolutionary and prognostic (time of hospitalization, length of hospital stay, evolutionary modalities) were also collected from patients' files.

Data entry was done using Epi-Data software version 3.5.1 and their exploitation was done using the Epi-info software version 7.1.5.0.

The categorical variables were expressed in proportions and the quantitative variables in mean \pm standard deviation (in the case of normal distribution) or in the median and extreme (in the case of non-normal distribution).

\section{Results}

\subsection{Epidemiological Data}

During the 24 months of our study, 1922 patients were hospitalized, including 129 cases of enterobacterial infections, a prevalence of $6.71 \%$. The average age of the patients was 41 years with extremes of 14 and 92 years. The age group between 20 - 40 years was the most represented with $44.2 \%$ as shown in Table 1. Female were predominant (60\%) with a sex ratio of 0.67 , mostly from suburban areas $(44.7 \%)$. Of those whose marital status was investigated (92 cases), more than half (61.9\%) were married. Regarding the profession, it was only reported in 53 patients. They were mostly housewives with 17 cases or $32.1 \%$.

When it comes to comorbidities, they were found in 114 patients. This was most common in HIV infection, 97 cases, or $85 \%$ of co-morbidities and high blood pressure in 14 patients, or $12.3 \%$.

\subsection{Clinical Data}

Of the clinical signs, infectious syndrome (53.49\%), general impairment (40.31\%) and pulmonary condensation syndrome (22.48\%) were the most common. The primary gateway was urinary in more than half of the cases (55.8\%) (Figure 1) and HIV infection was the most commonly associated diagnosis $(75.2 \%, \mathrm{n}=97)$, followed by urinary tract infections $(31.8 \%, \mathrm{n}=41$ cases) and septicemia (17.8\%, $\mathrm{n}=23$ cases) (Figure 2 ).

Table 1. Patient Distribution by Age group.

\begin{tabular}{ccc}
\hline Age group & Population (n) & Relative frequency (\%) \\
\hline$<20$ & 5 & $3.9 \%$ \\
$\mathbf{2 0}$ to $\mathbf{4 0}$ & 57 & $44.2 \%$ \\
$\mathbf{4 0}$ to 60 & 50 & $38.8 \%$ \\
$\mathbf{6 0}$ to 80 & 14 & $10.9 \%$ \\
$>80$ & 3 & $2.3 \%$ \\
Total & 129 & 100 \\
\hline
\end{tabular}




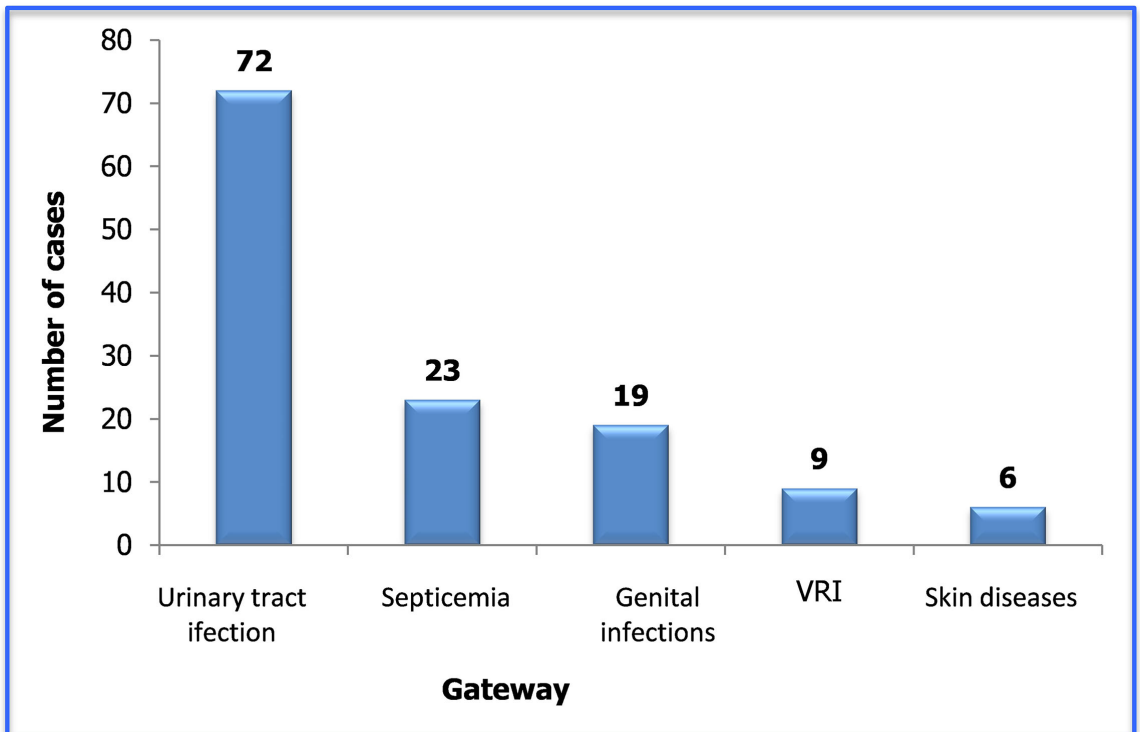

Figure 1. Distribution of patients by gateway.

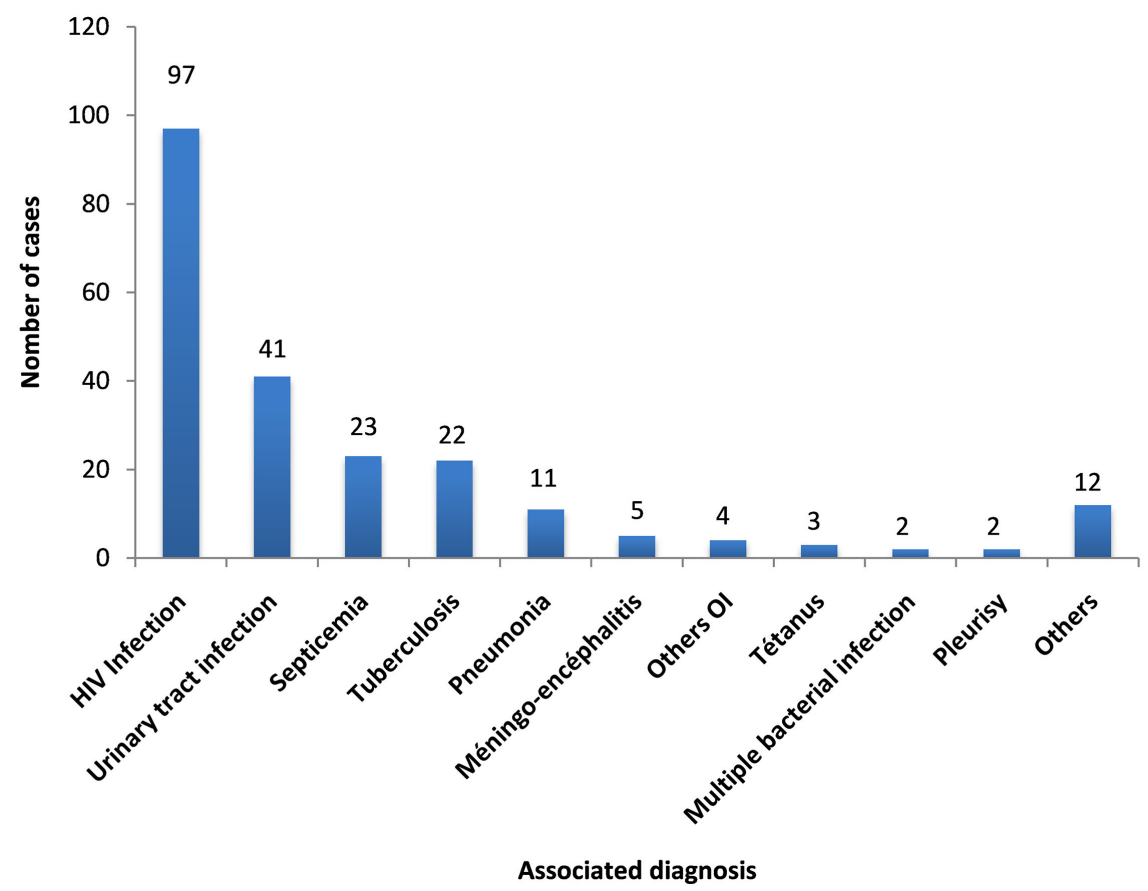

Figure 2. Distribution of patients based on the associated diagnosis. ${ }^{*}$ Other: ${ }^{\star}$ GEA ${ }^{\star}$ Psoas infection ${ }^{\star}$ Infected lymphadenopathy ${ }^{\star}$ Sepsis ${ }^{\star}$ Basedow ${ }^{\star}$ Kaposi.

\subsection{Paraclinical Data}

More than half of the patients in our study population (70 cases or $55.1 \%$ ) had moderate anemia and more than one-third had severe anemia (39.4\%) with an average hemoglobin count of $8.6 \mathrm{~g} / \mathrm{dl}$. The average white blood cell count was 8950.01 and one quarter of patients had leukocytosis. $2 / 3$ of patients had neutropenia. The average CRP level was $80.47 \mathrm{mg} / \mathrm{L}$, glycemia at empty stomach was $0.95 \mathrm{mg} / \mathrm{L}$. In most cases (77.1\%), the blood glucose was normal. 
For those in the study population who had HIV infection, the average TCD4 + cell count was 87.82 cells $/ \mathrm{mm}^{3}$, and almost all $83 \%$ had a CD4 + T cell count of less than 200 cells $/ \mathrm{mm}^{3}$.

\subsection{Bacteriological Data}

Samples were monomicrobial in more than $3 / 4$ cases $(76.7 \%)$ and the most frequently isolated enterobacteria were Klebsiella (57 strains) and Escherichia (54 strains) (Figure 3). However, as shown in Figure 4 in the polymicrobial samples, the most isolated were Klebsiella pneumoniae + Staphylococcus aureus (5 cases) and Klebsiella pneumoniae + Acinetobacter (4 cases).

Table 2 summarizes all cases of antibiotic resistance. In fact, isolated Klebsiella, Escherichia and Enterobacter strains exhibited high resistance to third generation cephalosporins (C3G), aminoglycosides, ciprofloxacin and cotrimoxazole. Salmonella infections were sensitive to most of the antibiotics tested except cotrimoxazole and amoxicillin-clavulanic acid (20\%). The Proteus strains had high levels of resistance to C3G (66.66\%). Finally, the resistance of enterobacterial strains isolated to imipenem did not exceed $4 \%$.

Table 2. Distribution of cases by antibiotic resistance.

\begin{tabular}{|c|c|c|c|c|c|c|c|c|}
\hline $\begin{array}{l}\text { Antibiotics } \\
\text { seed }\end{array}$ & $\begin{array}{l}\text { Salmonella } \\
\mathrm{N}=5(\%)\end{array}$ & $\begin{array}{l}\text { Escherichia } \\
\mathrm{N}=53(\%)\end{array}$ & $\begin{array}{c}\text { Klebsiella } \\
\mathrm{N}=55(\%)\end{array}$ & $\begin{array}{c}\text { Enterobacter } \\
\mathrm{N}=18(\%)\end{array}$ & $\begin{array}{c}\text { Proteus } \\
\mathrm{N}=3(\%)\end{array}$ & $\begin{array}{c}\text { Serretia } \\
N=1(\%)\end{array}$ & $\begin{array}{c}\text { Citrobacter } \\
N=2(\%)\end{array}$ & $\begin{array}{c}\text { Providentia } \\
\quad N=1\end{array}$ \\
\hline Amoxicilline & $1(20 \%)$ & $31(54.5 \%)$ & $35(63.6 \%)$ & $12(66.7 \%)$ & $1(33.3 \%)$ & $0 \%$ & $1(50 \%)$ & $100 \%$ \\
\hline $\begin{array}{l}\text { Amoxicillin-clavulanic } \\
\text { acid }\end{array}$ & $1(20 \%)$ & $35(66 \%)$ & $47(85.4 \%)$ & $14(77.8 \%)$ & $0 \%$ & $100 \%$ & $1(50 \%)$ & $100 \%$ \\
\hline $\begin{array}{l}\text { 3rd generation } \\
\text { cephalosporin }\end{array}$ & $0 \%$ & 27 (50.9\%) & $30(54.5 \%)$ & $11(61.1 \%)$ & $2(66,7 \%)$ & $0 \%$ & $2(100 \%)$ & $100 \%$ \\
\hline Ciprofloxacin & $0 \%$ & $29(54.71 \%)$ & $30(54.5 \%)$ & $5(27.8 \%)$ & $0 \%$ & $100 \%$ & $0 \%$ & $0 \%$ \\
\hline Peéloxacine & $0 \%$ & $7(13.20 \%)$ & $6(10.90 \%)$ & $1(5.55 \%)$ & $0 \%$ & $0 \%$ & $0 \%$ & $0 \%$ \\
\hline Imipenem & $0 \%$ & $2(3.77 \%)$ & $1(1.81 \%)$ & $0 \%$ & $0 \%$ & $0 \%$ & $0 \%$ & $0 \%$ \\
\hline Piperacillin & $0 \%$ & $10(18.86 \%)$ & $17(30.9 \%)$ & $1(5.5 \%)$ & $0 \%$ & $0 \%$ & $0 \%$ & $0 \%$ \\
\hline Kanamycin & $0 \%$ & $11(20.7 \%)$ & $24(43.4 \%)$ & $4(22.2 \%)$ & $0 \%$ & $0 \%$ & $0 \%$ & $0 \%$ \\
\hline Gentamicin & $0 \%$ & $11(20.7 \%)$ & $22(40 \%)$ & $4(22.2 \%)$ & $0 \%$ & $0 \%$ & $0 \%$ & $0 \%$ \\
\hline Cotrimoxazole & $1(20 \%)$ & $25(41.2 \%)$ & $29(52.7 \%)$ & $7(38.9 \%)$ & $0 \%$ & $0 \%$ & $1(50 \%)$ & $0 \%$ \\
\hline Oxacillin & $0 \%$ & $0 \%$ & $2(3.6 \%)$ & $1(5.5 \%)$ & $0 \%$ & $0 \%$ & $0 \%$ & $0 \%$ \\
\hline Lincocin & $0 \%$ & $0 \%$ & $0 \%$ & $0 \%$ & $0 \%$ & $0 \%$ & $0 \%$ & $0 \%$ \\
\hline Erythromycin & $0 \%$ & $0 \%$ & $1(1.81 \%)$ & $0 \%$ & $0 \%$ & $0 \%$ & $0 \%$ & $0 \%$ \\
\hline Fusidic acid & $1(20 \%)$ & $0 \%$ & $24(43.4 \%)$ & $6(33.3 \%)$ & $0 \%$ & $0 \%$ & $1(50 \%)$ & $0 \%$ \\
\hline Vancomycin & $0 \%$ & $0 \%$ & $0 \%$ & $0 \%$ & $0 \%$ & $0 \%$ & $0 \%$ & $0 \%$ \\
\hline Aztreonam & $0 \%$ & $21(39.6 \%)$ & $17(30.9 \%)$ & $3(16.6 \%)$ & $2(66.6 \%)$ & $0 \%$ & $1(50 \%)$ & $0 \%$ \\
\hline
\end{tabular}




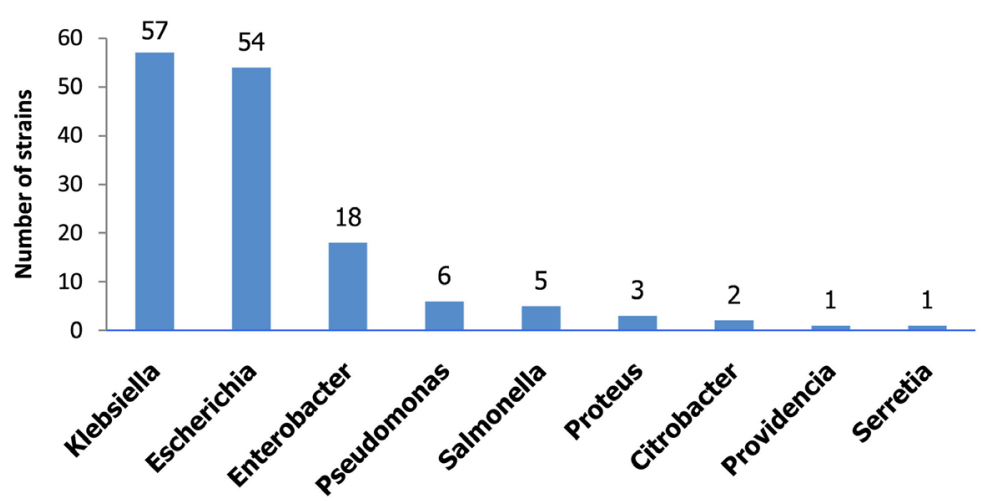

Figure 3. Distribution according to the different germs of isolated enterobacteria.

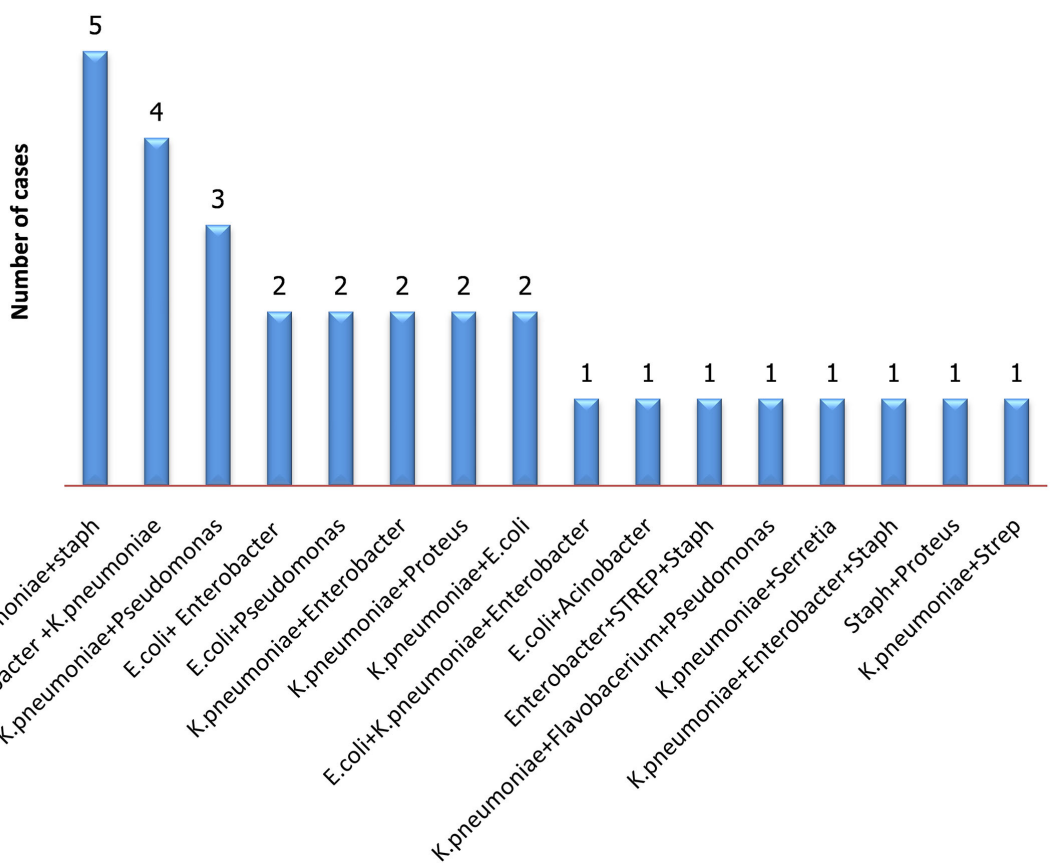

Figure 4. Distribution of isolated bacteria according to poly-microbial samples.

\subsection{Therapeutic and Evolutionary Data}

In the study population, 88 patients or $68.7 \%$ had received probabilistic treatment. More than $65.9 \%$ of patients received poly antibiotic therapy with the most $(43.2 \%)$ use of two antibiotics. In monotherapy, ceftriaxone was the most commonly used antibiotic (50\%) and in dual therapy the amoxicillin-clavulanic acid plus spiramycin combination was the most commonly used (21.1\%).

The average time of hospitalization was 35 days. Most of the patients were hospitalized 30 days after the onset of symptoms for a hospital stay of more than 30. In addition, the average hospital stay was 27 days.

In more than 2 out of 5 of the cases, the evolution led to death, $41.1 \%(n=53)$.

\section{Discussion}

During our study period, we had a proportional morbidity of $6.71 \%$ and a sex 
ratio of 0.67 dominated by women. This view is shared by the literature. In Senegal, a female predominance was noted in the study conducted by Lo et al. [4] in 2014, which found $52.7 \%$ of women and the one of Dia et al. [5] also conducted in 2014, which found a sex ratio of 0.85 . On the contrary, in 2015, Diallo [6] found a male predominance with a sex ratio of 1.7. This male predominance in Diallo's study can be explained by the fact that it concerned all ages, unlike many studies that laid the emphasis on adults.

Elsewhere in Africa, and specifically in Morocco, Elfane et al. [7] reported a sex ratio of 1.5 with female predominance. Ditto for Amhaouch $\mathrm{Z}$ et al. [8], who had objectified this same female predominance.

In France, and specifically in Guyana, C Baizet [9] also found a female predominance with a sex ratio to 0.3 in her study.

This leads to the assumption that the female predominance is mainly since most of the results are from studies on nosocomial urinary infections that occurred most of the time during surveys. The 20- and 40-year-old age group more frequently observed in our study population was different from the age group in the studies of Diallo and [6] and Diop [10] whose study population was over 50 years old. This difference can be explained by the fact that these are rather compartmental studies considering only uro-pathogenic enterobacteria while ours takes them into account thoroughly.

Patients were mainly from suburban area (44.7\%). In such zone, hygienic conditions are often poor, mostly related to a low purchasing power but especially to the precariousness in which the patients live. This exposes them even more to infections that can affect the prognosis of patients.

Of the comorbidities found, HIV infection was widely represented. This predominance was the same as in Tchegho's study [11]. This preponderance of people living with HIV (PLHIV) constitutes a selection bias because the Clinic of infectious diseases is the reference center dedicated to the treatment of people infected by HIV. Thus, they represent the $2 / 3$ of hospitalized people. Moreover, because of their often very advanced immunodepression, they are prone to BGN infections, and most specifically to enterobacteria.

Clinically, the rate of HIV-infected patients in our series (75.2\%) with severe immunosuppression (CD4 count $<200$ cells $/ \mathrm{mm}^{3}$ ) of $85.6 \%$ could explain the frequency of the alteration of the general state. As for pulmonary condensation, it was mainly due to pulmonary tuberculosis, which is the first opportunistic infection in Senegal [12].

The associated diagnosis was dominated by HIV infection, which is a favorable area for the occurrence of enterobacterial infections.

The most common gateway was urinary tract infection (55.8\%). This may be of community origin (extrinsic or intrinsic obstacles) or nosocomial (indwelling urinary catheter, instrumental maneuvers). It is the most frequent entry point for Enterobacteriaceae, especially in Cameroon [13]. They also accounted for $68.7 \%$ of isolated urine germs in the Khaira study on broad-spectrum beta-lactamase secreting enterobacteria (EBLSE) [14]. 
Regarding the biological aspects, a quarter of our study population had leukocytosis that could be related to the severe immunosuppression of almost all the study population living with HIV but also to the inflammatory response in response to the presence of a microorganism.

Bacteriologically, bacteriological examination was in most cases mono-microbial (76.7\%) and polymicrobial in $23.3 \%$. The main germs identified were Klebsiella, Escherichia and Enterobacter.

The predominance of these Enterobacteriaceae has also been demonstrated in other studiesin Cameroon (71\%), Dakar (86.24\%) and Morocco (25\% in 2012) [13] [15] [16].

\section{- The Klebsiella}

Klebsiella pneumoniae is one of the microorganisms that deserves special attention because of growing resistance problems that cause a high number of infections acquired in health facilities or in the community. They mainly infect the urinary and respiratory tracts or cause bacteremia [17].

In our study Klebsiella pneumoniae was the most represented organism with $38.8 \%$ of isolated strains. This predominance was also noted in other studies. Notablyat Fann Hospital with 38.07\% [16] and in Morocco with 4\% in 2008 and 6\% in 2012 [16]. These strains exhibited significant resistance to C3G, aminoglycosides and ciprofloxacin. This is a worrying situation which is mainly related to the misuse of antibiotics inducing the emergence of multidrug-resistant strains. Such levels of resistance have also been found in similar work: more than $70 \%$ resistance in a study done at Fann bacteriology laboratory [15], 15\% in MKAOUAR' study [18], 60\% in another series at Fann hospital [19]. To solve this problem, it is necessary to build the capacity of practitioners by training them to prescribe antibiotics according to recommendations.

\section{- Escherichia species}

They are responsible for more than $80 \%$ of community-acquired UTIs and $40 \%-50 \%$ of those acquired in hospitals [1].

In our study, Escherichia also had significant resistance to $\mathrm{C} 3 \mathrm{G}$, aminoglycosides and ciprofloxacin but also to amoxicillin. In recent years, there has been an increase in E. coli resistance to some previously effective antibiotics such as amoxicillin [20] [21] [22]. Likewise, in our study we noted resistance to amoxicillin in more than half of the cases. This observation was not only made in Senegal $20 \%$ of resistance to amoxicillin [22] but also in France with $60 \%$ of resistance [23]. In about 20 years, resistance to C3G, aminoglycosides and ciprofloxacin worsened in the Clinic. At that time, it was estimated only around 10\% [24]. This situation reflects the dangerous evolution of antibiotic resistance often due to their inappropriate use.

\section{- Enterobacter species}

Enterobacter species are often found in intensive care units and account for $8.6 \%$ of nosocomial infections, according to the Center for Disease Control and Prevention (CDC) [25]. 
Resistance of Enterobacter to amoxicillin is estimated at $66.67 \%$. These results are close to that of Sanaa [26]. This may also be related by the fact that there is a natural resistance of Enterobacter to amoxicillin by production of betalactamases [27].

However, all Enterobacter species tested were sensitive to lincocine, erythromycin and to vancomycin.

\section{- Les Salmonella species}

Salmonellae have good sensitivity for all antibiotics tested; sensitivity varies between $80 \%$ and $100 \%$. As stipulated by the Francophone journal of laboratories [28], African salmonella strains are very sensitive. The rate of this sensitivity was similar to the one found in a Moroccan study [29].

\section{- Les Proteus species}

It is a germ which sensitive to most antibiotics tested at $100 \%$ except for amoxicillin, C3G, and aztreonam. Many studies have shown the sensitivity of Proteus to various antibiotics especially for Aminoglycosides (gentamicin and kanamycin) [30] [31].

- Citrobacter species

Citrobacter was $100 \%$ sensitive to most antibiotics tested. However, there was a total resistance against C3G. Tine [22] found greater resistance for some germs with $100 \%$ for cotrimoxazole.

Therapeutically and progressively, more than half of the study population received probabilistic antibiotic therapy. In this group the majority had benefited from bi-antibiotic therapy. The most commonly used molecule in monotherapy (50\%) or in combination was Ceftriaxone, a similar finding had already been made elsewhere in Europe [32] [33].

In our study, the lethality was very high, testifying to the severity of enterobacterial infections, especially when they occur on certain specific sites such as immunosuppression due to HIV. This mortality is often related to the high resistance to the usual antibiotics. It would be necessary to conduct further studies to identify the factors associated with this important lethality.

\section{Conclusions}

In recent years, we have seen an increase in the resistance of enterobacteria to antibiotics that were previously very sensitive to them. The increase in resistance is mainly due to a high rate of probabilistic treatment, to self-medication by antibiotics but also to misuse of antibiotics. This resistance is at the origin of the restriction of the number of effective antibiotics chosen in first intention, of the use of a poly-antibiotherapy more and more in first intention and the increase of the therapeutic failures.

Thus, from this study it appears that measures should be taken by the authorities, to fight against antibiotic resistance by setting up a surveillance program for antimicrobial resistance including enterobacteria.

In addition, it is necessary to develop antibiotic prescribing guidelines adapted 
to our context, and to organize updating meetings regularly. Concerning health care providers, they should carry out undertake a strict asepsis during treatment and make sure antibiotics are prescribed according to the recommendations.

On the other hand, the sensitization of the consequences with regards to self-medication and compliance with the prescription period of antibiotics would be of great benefit.

\section{Authors' Contribution}

List of authors who contributed to the study:

- Dr. Ndèye Aissatou Lakhe contributed to the analysis, interpretation, and correction

- Dr. Khadime Sylla contributed to the analysis, correction and proofreading

- Dr Rahmatoulahi Ndiaye contributed to the data analysis

- Pr Cheikh Tidiane Ndour contributed to the design of the study, analysis and correction

- Dr. Daye Ka helped proofreading

- Dr. Viviane Marie Pierre Cissé Diallo contributed to the proofreading

- Dr. Aminata Massaly contributed to the proofreading

- Dr. Alassane Dièye contributed to the proofreading

- Prof. Louise Fortes Déguenonvo contributed to the proofreading

- Dr. Cheikh Tacko Diop contributed to the proofreading

- Pr Masserigne Soumaré contributed to the proofreading

- Prof. Moussa Seydi contributed to the proofreading

\section{Conflicts of Interest}

The authors declare no conflicts of interest regarding the publication of this paper.

\section{References}

[1] Verhaegen, J. (2017) Bactériologie. Les entérobactéries-Médecine. http://m.20-bal.com/law/5094/index.html

[2] Infection Microbienne. les Bacilles Gram négatifs aéro-anaérobies facultatifs. http://gric-univ-lyon.fr/gric3/decouverte/document/notesdecours/les\%20infections \%20microbiennes.htm

[3] Belmonteo, O., Drouetd, D., Albaj, J., Moiton, M.-P., Kuli, B., Lugagne-Delpon, N., et al. (2010) Evolution de la résistance des entérobactéries aux antibiotiques sur l'Iles de la Réunion: Émergence des betalactamases à spectre élargi. Pathologie Biologie, 58, 18-24. https://doi.org/10.1016/j.patbio.2009.07.021

[4] Lo, S. (2014) Sensibilité aux antibiotiques des entérobactéries isolées d'urine au CHR de Saint-Louis (Sénégal) de juin 2011 à juillet 2012. Rev Cames Santé, 2, 25-28.

[5] Dia, M.L., Chabouny, H., Diagne, R., Ka, R., Ba-Diallo, A., Lô, S., et al. (2015) Profil antibiotypique des bactéries uropathogènes isolées au CHU de Dakar. Uro'Andro, 1, 212-217.

[6] Diallo, C.A. (2015) Epidémiologie et profil de sensibilité des entérobactéries Uro- 
pathogènes isolées au laboratoire de bactériologie du CHNU Aristide Le Dantec Thèse, Pharm. Dakar, No. 132.

[7] Elfan, M., Jebbar, S., Daoudi, N., Sodqi, M., Chakib, A., Ouladlahsen, A., et al. (2016) Infections urinairesnosocomiales: Profil épidémiologique et bactériologique. Médecine et maladies infectieuses, 46, 59; IAS-03.

[8] Amhaouch, Z., Bergui, I. and Figuigui, S. (2013) Profil de résistance des entérobactéries urinaires au CHU HASSAN II-Fes. In $5^{\text {ème }}$ Journées Scientifiques de la Société Marocaine de Microbiologie Médicale, PB8.

[9] Baizet, C., Ouar, E.S., Demar, M., Djossou, F., Egmann, G. and Epelboin, L. (2016) Facteurs de risque d'infections urinaires à entérobactéries BLSE dans un service d'urgences en région Amazonienne. Médecine et maladies infectieuses, 46, 25; BMR-04

[10] Diop, N.D.A. (2013) Antibiorésistance des souches d'entérobactéries uropathogènes productrices de bétalactamases à spectre étendu d'origine communautaire à Dakar: Mémoire Master II Micro Bio Fondamentale.

[11] Tcheghokcb (2016) Profil des infections urinaires au service des Maladies Infectieuses et Tropicales de Dakar: À propos de 98 cas. Thèse Med, Dakar, No. 8.

[12] Programme national de lutte contre la tuberculose au Sénégal (PNT) (2009) Rapport annuel.

[13] Ebongue, O.C., Tsiazok, D.M., Mefo'o, N.J.P., Ngaba, G.P., Beyiha, G. and Adiogo, D. (2015) Evolution de la résistance aux antibiotiques des entérobactéries isolées à l'hôpital général de Douala de 2005 à 2012. Pan African Medical Journal, 20, 227. https://doi.org/10.11604/pamj.2015.20.227.4770

[14] Avril, J., Monteil, D.F. and Monteil, H. (2000) Bactériologie Clinique. 3rd édition, Ellipse, Paris.

[15] Oumy, K.H.N. (2005) Les entérobactéries sécrétrices de betalactamases à spectre élargi: Étude des souches isolées au laboratoire du CHU de Fann de 2000 à 2004. Thèse Pharm, Dakar, No. 37.

[16] Bouamri, M.C.E.L., Arsalane, L., Kamouni, Y., Berraha, M. and Zouhair, S. (2013) Evolution récente du profil épidémiologique des entérobactéries Uropathogènes productrices de bete-lactamases à spectres élargi à Marrakech, Maroc. Progrès en Urologie, 24, 451-455. https://doi.org/10.1016/j.purol.2013.11.010

[17] Holt, K.E., Wertheim, H., Zadoks, R.N., Baker, S., Whitehouse, C.A., Dance, D., et al. (2015) Genomic Analysis of Diversity, Population Structure, Virulence, and Antimicrobial Resistance in Klebsiella Pneumonia, an Urgent Threat to Public Health. Proceedings of the National Academy of Sciences of the United States, 112, 3574-3581. https://doi.org/10.1073/pnas.1501049112

[18] Mkaouar, D., Mahjoubi, F., Mezghani, S., Znazen, A., Ktrari, S. and Hammami, A. (2008) Etude de la résistance des entérobactéries aux céphalosporines de troisième génération dans les hôpitaux de Sfax, Tunisie (1999-2005). Médecine et Maladies Infectieuses, 38, 293-298. https://doi.org/10.1016/j.medmal.2007.11.017

[19] Dorcas, H.E.E. (2016) Les bactériémies au service des maladies infectieuses et tropicales de Fann à Dakar : Etude descriptive de 2013 à 2014. Thèse Med, Dakar, No. 35.

[20] Alloch, P.Y., Labia, R., Pina, P. and Morin, E. (1995) Observatoire hospitalier de la sensibilité d'E. coli et de Klebsiella à l'association amoxicilline-acide clavulanique en 1994. Médecine et Maladies Infectieuses, 25, 934-939.

https://doi.org/10.1016/S0399-077X(05)81150-3

[21] Lemort, M.L., Neuville, S., Medus, M., Gueudet, P., Aumaitre, H. and Lecaillon, E. 
(2006) Evolution de la sensibilité des souches d'Escherichia coli isolées d'infection urinaires des patients consultants aux urgences et de patients hospitalisés en 2002 et 2004 à l'hôpital de Perpignan. Pathologie Biologie, 54, 427-430.

[22] Tine, N.N. (2009) Aspects cliniques, bactériologiques et profils de sensibilité des infections urinaires: Étude multicentrique à propos de 120 cas. Thèse Med, Dakar, No. 103.

[23] Trivalle, C., Lopez, T.F., Minozzi, C. and Mathieu, D. (2006) Bacterial Ecology of Urine Isolates from Elderly Hospitalized Patients: Incentive to Empirical Therapy. La Revue de Gériatrie, 31, 77-82.

[24] Seydi, M., Sow, P.S., Soumare, M., Ndour, C.T., Dia, N.M., Diop, B.M., et al. (2003) Les bactériémies au cours du Sida à Dakar, Sénégal. Médecine et Maladies Infectieuses, 33, 323-326. https://doi.org/10.1016/S0399-077X(03)00121-5

[25] Boyce, T.G., Gruber, W.C. and Fisher, R.G. (2004) Enterobacter. In: Textbook of Pediatric Infectious Diseases, 5th Edition, Saunders, Philadelphia, 1427-1431.

[26] Sanaa, S. (2007) Profil de l'ECBU au CHU Ibn Rochd de Casablanca à propos de 537 sujets porteurs de sonde vésicale. Thèse Pharm, Dakar, No. 27.

[27] Lee, M.E., Altmark, L., Shapiro, M. and Moses, A.E. (2001) Antimicrobial Resistance Patterns among Urine Isolates from Patients in a Geriatric Hospital and from Older Patients in a General Hospital in Jerusalem. Journal of the American Medical Directors Association, 2, 34-40. https://doi.org/10.1016/S1525-8610(04)70152-8

[28] Weill, F.X. (2008) Salmonella: Épidémiologie, typage, et résistance aux antibiotiques. Revue Francophone des Laboratoires, No. 400, 37-47. https://doi.org/10.1016/S1773-035X(08)80099-8

[29] Soraa, N., Zougaghi, L. and Zahlane, K. (2011) Epidémiologie et profil de sensibilité des isolats d'hémocultures dans un centre Hospitalo-Universitaire Marocain. Revue Tunisienne Infect, 5, 78-81.

[30] Dieneif (1998) Infections urinaires nosocomiales dans le service d'urologie du CHU A. Le Dantec: Etude de l'écologie bactérienne. Thèse Pharm, Dakar, No. 55.

[31] Niang, S. (2001) Infections urinaires nosocomiales: Incidence et facteurs de risque au service d'urologie du CHU le Dantec. Thèse Pharm, Dakar, No. 120.

[32] Viallon, A., Marjollet, O., Leveques, Y., Robert, F., Berger, C., Pouzet, V., et al. (2007) Antibiothérapie chez des patients bactériemiques admis aux urgences: Analyse de la pertinence. Journal Européen des Urgences, 20, 70-76. https://doi.org/10.1016/j.jeur.2007.01.005

[33] Carot, J.F., Floret, N., Draou, B., Daucourt, V., Sakho, A., Blanc, E., et al. (2013) Analyse rétrospective de l'antibiothérapie probabiliste des infections basses chez des patients admis aux urgences du centre hospitalier Louis-Jaillon (Saint-Claude, France). Journal Européen des Urgences, 25, 141-146. 